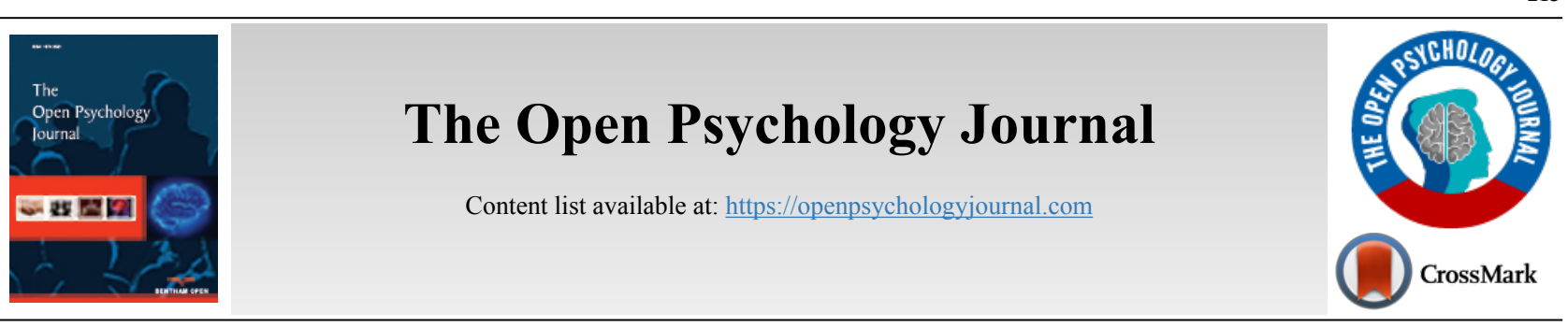

RESEARCH ARTICLE

\title{
Group Play Therapy for Preadolescents: Post-Traumatic Stress Disorder of Natural Disaster Victims in Indonesia
}

\author{
Nandang Rusmana ${ }^{1}$, Anne Hafina ${ }^{1}$ and Dodi Suryana ${ }^{1, *}$ \\ ${ }^{\prime}$ Department of Guidance and Counseling, Faculty of Education, Universitas Pendidikan Indonesia, Bandung, Indonesia
}

\begin{abstract}
:
Background:

This study was motivated by the failure of coping and adaptation to traumatic experiences that cause a wide, deep, and long-term snowball effect that may not be reversible.

Objective:

This study aims to test the effectiveness of the implementation of group play therapy in dealing with post-traumatic stress disorder (PTSD) victims of natural disasters in three provinces in Indonesia.

\section{Materials and Methods:}

The study employed an explanatory mixed methods design. The procedures and steps taken in this study refer to the research and development cycle. The subjects and objects of the study were 106 male and 92 female preadolescent students of junior high school in three provinces in Indonesia.

\section{Results:}

Traumatic counselling through group play therapy techniques has the effect of reducing post-traumatic stress disorder on victims of the tsunami disaster in three provinces in Indonesia. The first study conducted in Lombok West Nusa Tenggara province obtained the results of the calculation of the value $\mu_{2}=0.021$ for the value of $\mu_{1>}$ 0.05. The second study in Palu, Central Sulawesi Province obtained the results of the calculation of the value of $\mu_{2}=0.018$ for the value of $\mu_{1>} 0.05$, and the third study in Anyer, Banten province obtained the results of the calculation of the value of $\mu_{2}$ $=0.011$ for the value of $\mu_{1}>0.05$.

Conclusion:

Teaching and practising the skills of traumatic counselling using using Group Play Therapy can handle PTSD victims of natural disasters that significantly change victims.
\end{abstract}

Keywords: Post traumatic stress disorder, Group play therapy, Traumatic counselling, Victims, Preadolescents, Earth quake.

\begin{tabular}{l|l|l|l} 
Article History & Received: January 8, 2020 & Revised: May 11, 2020 & Accepted: May 17, 2020
\end{tabular}

\section{INTRODUCTION}

Indonesia is located in the ring of fire, which stretches around the Pacific rim. This horseshoe-shaped region covers an area of $40,000 \mathrm{~km}$. About $90 \%$ of earthquakes and $81 \%$ of the biggest earthquakes occur in this area. Recently, Indonesia has experienced severe natural disasters that have caused damage, loss, and changes in psychological dynamics of ordinary to

\footnotetext{
* Address correspondence to this author at the Department of Guidance and Counseling, Faculty of Education, Universitas Pendidikan Indonesia, Bandung, Indonesia; Tel: +628122116766; E-mail: nandangrumana@upi.edu
}

serious and even emergency intensity. Conditions of psychological change are categorized as Post-Traumatic Stress Disorder (PTSD) [1].

Data from the Indonesian National Board of Disaster Management (BNPB) of 2017 to 2019 demonstrate that there were 8,305 natural disasters. More than 2700 people died and disappeared and more than 22,000 people were injured. and $14,690,228$ people were suffering and evacuated. In 2018, there was an earthquake in Lombok. Based on data from the National Agency for Natural Disaster Management, 436 people died and disappeared, 2,036 injured, and 352,793 were 
suffering and evacuated.

The data were obtained only from a few samples of victims of natural disasters. It is believed that far more victims of natural disasters are not recorded or reported. Epidemiological studies worldwide have documented that natural disasters are very high events affecting Post-Traumatic Stress Disorder (PTSD) [2]. Study results [3] have even shown that emotional wounds that result from experiencing tragic and extraordinary events and that more women are at risk of experiencing PostTraumatic Stress Disorder (PTSD).

PTSD is a psychiatric disorder that can occur following the experience or witnessing of life-threatening events such as military combats, natural disasters, terrorist incidents, serious accidents, or violent personal assaults [4]. Preadolescents who suffer from PTSD often relive the re-experienced events that are marked by the behavior of bringing up disturbing events (images, thoughts, or perceptions); recalling nightmares about an event (feelings reappear, illusions, hallucinations, and back to the dissociative past); symptoms of avoidance are marked by avoiding thoughts and feelings that can be reminiscent of traumatic events, reduced interest or real participation, feelings of alienation, inability to feel the tenderness of the heart, and symptoms of life disrupted that are marked distress in social functions or other important areas. These symptoms can be severe enough and last long to significantly impair a person's daily life.

The importance of handling Post-Traumatic Stress Disorder (PTSD) was stated in a study [5 - 7], which revealed that "catastrophic stress" representing preadolescents who experienced an ordinary stressor or adjustment stressor and their potential ability to handle it because of differences in their capacity to confront the incident. The effects of PTSD on preadolescents are manifested in various disorders including physical, emotional, mental, behavioral, and spiritual fatigue [5, 8 - 11] (1) The mental fatigue symptoms include confusion, inability to concentrate and remember, and lack of decisionmaking ability; (2) the effects of PTSD emotional fatigue include irritation, moodiness, fear, exaggerated emotions, and loss of confidence; (3) fatigue behavior is manifested among others in sleeping difficulty, loss of appetite, overeating, excessive smoking, alcohol consumption, avoidance, irritability, self-confinement, excessive shame, fidgetting, agitation, and being suicidal; (4) symptoms of physical fatigue include tension, trembling, fatigue, tingling, nausea, digestive tract problems, rapid breathing, and even panic attacks; and (5) spiritual fatigue shows symptoms of discouragement, hopeless, blaming God, stopping worship, despair, doubting beliefs, and not being sincere.

The phenomenon of post-traumatic stress disorder is of serious concern as Indonesia has already had a set of the regulatory platform on disaster management. This is indicated by the issuance of Law on Republic of Indonesia Law Number 24 the Year 2007 concerning Disaster Management, including Disaster Management, Republic of Indonesia Government Regulation Number 21 concerning Disaster Management, Republic of Indonesia Government Regulation Number 23 the Year 2008 concerning Participation of International Institutions and Foreign Institutions Non-Government in Disaster
Management, and Presidential Regulation Number 8 the Year 2008 concerning the National Disaster Management Agency.

Part Four of Government Regulation Number 22 of 2008 on Post-Disaster states that post-disaster management is focused on rehabilitation and reconstruction efforts, including environmental improvement of the disaster area, reconstruction of public facilities and infrastructure, providing assistance to rebuild community houses, psychological social recovery, health services, reconciliation and conflict resolution, socioeconomic recovery, restoration of security and order, restoration of government functions, and restoration of public service functions. However, as with the existing legislation, more efforts seem to have been focused on managing disaster overall risks, which have not produced optimal results. Disaster management is a collective issue of the community in which education is expected to provide effective and reliable models and strategies and, at the same time, strengthen policy institutions and existing legislation.

This study is a follow-up research on traumatic counselling and various game applications to resolve the conflict in Ambon, Central Maluku, Buru Island, Ternate, Poso, Sampit, Madura, tsunami victims in Aceh, Nias, Ciamis, and Pangandaran, flood victims in Jember and Banjarnegara, and victims of Mount Merapi eruption in Yogyakarta. The findings show that traumatic counselling using game techniques can potentially be used effectively to handle post-traumatic stress disorder (PTSD) of victims of natural disasters. The games have psychologically encouraged the preadolescents to laugh, smile, cooperate, run, and embrace [12].

Guidance and counselling are an integral part of education. The handling of Post-Traumatic Stress Disorder (PTSD) representing individuals should be put in the perspective of facilitating the stages of physical, social, emotional, and spiritual development that can again develop in a constructive direction.

Based on the results of the latest literature studies and research, post-traumatic stress disorder (PTSD) can be reduced through cognitive-behavioral therapy that aims to change the emotions, thoughts, and behavior of individuals [13 - 15]; pharmacotherapy techniques that use drugs to reduce anxiety, depression, insomnia, distress and numbness; eye movement desensitization and reprocessing techniques that combine exposure and cognitive-behavioral therapies by putting parts of the body in motion [16 - 20]; group treatment techniques that give the individuals an opportunity to share empathy, cohesion, and security; and brief psychodynamic psychotherapy techniques that focus on emotional conflicts caused by trauma events, especially early in life.

The previous PTSD sub-study was more focused on the context of individual psychological dynamics that were very sustainable, but the existing approach tended to emphasize more on the task of adolescent and adult development, whereas the task of developing preadolescents deals more with spontaneous and natural emergent behavior. These considerations are the foundation for the follow-up.

Based on the phenomenon of Post-Traumatic Stress Disorder (PTSD) and findings as revealed in the previous sub, 
it is suspected that the failure of coping and adaptation to the traumatic experience that causes a wide, deep, and long-term snowball effect, may not be changeable (irreversible). In its extreme form, it will even result in social deprivation [11], [21].

Efforts to handle PTSD that are oriented towards long-term behavior; it requires ideas and innovations of a traumatic counselling approach that is packaged through responsive services with group play therapy. Play is considered as an educational medium that plays a role in increasing self-defence ability. The results of group play therapy studies have a connection to survival, provide a solid foundation for efforts to maintain the presence of games in human life, the ability to survive in their environment, and abilities, skills, and knowledge that are essential for survival. Play activities prevent boredom in the process of learning new skills and knowledge [21 - 24].

\section{MATERIALS AND METHODS}

\subsection{Overall Design}

The method used in this study is Mixed Methods Designs, which is an integration of quantitative data with qualitative data [25]. The Explanatory Mixed Methods Design is used because PTSD can be positioned philosophically both as a tool and a purpose; therefore, PTSD data would be incomplete if they are only examined as an outcome but not a process. Furthermore, preadolescent's behavior is a continuum that extends from simple to complex; therefore, the use of the two paradigms is deemed more comprehensive. Specifically, the quantitative approach is used to identify PTSD problems and to test the effectiveness of the group play therapy model. This study is aimed at measuring the effectiveness of traumatic counselling through group play therapy techniques for handling PTSD.

\subsection{Procedures}

The procedures and steps taken in this study refer to the R\&D and development cycle. According to a study [26], the research and development cycle consists of ten steps, namely; (1) research and data collection (research and information collecting), (2) planning (planning), (3) developing stage one model (develop a preliminary form of product), (4) preliminary field testing, (5) revision of the first stage model (main product revision), (6) field testing (main field testing), (7) revised model of the results of field tests (operational product revision), (8) field tests of operational models (operational field testing), (9) revisions of the final model (final revision), and (10) dissemination and implementation (dissemination and implementation).

Referring to the research objectives and practical considerations, in this study, the ten research steps of Borg \& Gall [26] were modified into seven main steps, namely (1) exploratory studies, (2) literature studies, (3) hypothetical model preparation, (4) verification and validation by experts and practitioners, (5) model revision, (6) model implementation, and (7) final model formulation.

\subsubsection{Explorative Study}

The explorative study was carried out to gain a deep understanding of the objective conditions of the field in support of conducting research. Exploratory studies of trauma are carried out through two activities, namely: (a) understanding of the urgency level of the research problem (need assessment) and (b) a deep understanding of the objective conditions of the field in supporting the conducted research. The need assessment step collected information about the number, variety, types, and depth of traumatic problems experienced by earthquake victims. Understanding of the objective conditions of the field was directed at efforts to understand in depth about the objective conditions of the location and place of research, synchronizing research time, community support, in carrying out research.

\subsubsection{Literature Review}

The literature study is the process of finding information about the framework of a group counselling model for preadolescents with traumatic experiences, especially relating to concepts, theories, and research reports about (a) posttraumatic stress disorder; (b) a group counselling model that deals with preadolescent with traumatic experiences, games as a method of psychotherapy, and relevant research reports. This literature study was conducted before the research began.

\subsubsection{Hypothetical Model Development}

A hypothetical model of group counselling for preadolescents with traumatic experiences was formulated at this stage. The model was built with component models, which included (a) rational, (b) objectives, (c) mechanisms and steps, (d) strategies and implementation techniques, (e) success criteria, and (f) evaluation models.

\subsubsection{Verification and Validation by Experts and Practitioners}

This stage is a hypothetical model rational testing process that is carried out by asking the opinions of experts and practitioners. Experts who were asked to weigh the feasibility of the hypothetical model were, (1) counselling experts, (2) group counselling experts; (3) preadolescents play experts, (4) preadolescents education experts; (5) counselling experts for preadolescent with a traumatic experience. Practitioners who were asked to provide a model feasibility scale were school counsellors and volunteers or practitioners who were involved in dealing with preadolescents with traumatic experiences. The experts were generally from the Indonesia University of Education, the number was five people, two of whom were counselling experts with a background of S3 in Guidance and Counseling, one group counselling expert with S2 background in Guidance and Counseling, one expert in guidance with the background of Masters in Guidance and Counselling, one child $\&$ preadolescents education expert with a Masters in Child \& Preadolescents Guidance and Counseling. The 12 practitioners and volunteers consisted of five alumni of Educational Psychology and Guidance and seven final year students who were completing studies on traumatic counselling at the Indonesia University of Education. The results of expert scales 
and expert reports are reported in Chapter IV.

Delphi technique was used in model validation by experts and practitioners. Delphi technique is an assessment technique for making decisions by sending a validation guide design model to the validators [19]. The results of the decisions of the validators are then drawn as a general decision.

\subsubsection{Model Revision}

At this stage, a hypothetical model which had been weighed by experts and practitioners by accommodating their suggestions and recommendations was formulated. The main target of this stage is to obtain a formulation of an operational model that is ready to be trialled.

\subsubsection{Model Effectiveness Test}

At this stage, the initial model was applied to the traumatic experienced preadolescents. The model effectiveness test was carried out using a quasi-experimental design with pre-post test models of Non-Equivalent Groups Design [27, 28]. The intervention given for the experimental group 1 was traditional games while the experimental group 2 was given nontraditional games. Preadolescents targeted in implementing the model were Preadolescents of the tsunami victims

\subsubsection{Model Formulation}

The process of formulating the model is the final activity of the research process. The model formulation process was carried out after a study of the results of the model implementation. The main objective of this activity was the formulation of the final model recommended as a result of research.

\subsection{Study Population}

A qualitative approach is used to conduct a study of the carrying capacity of the field and observation of the counselling process. The subject and object of the study were junior high school students who have basic psychological considerations because, at this age, the preadolescents have not been able to cope because of differences in the capacity of ways of thinking and acting to deal with events. The subjects were junior high school students aged 13-15 years old. In detail, the subjects and objects of research are shown in Table 1.

\section{RESULTS}

Empirical data were used to determine the effectiveness of group play therapy to resolve post-traumatic stress disorder.

T-test was used to test the effectiveness of group play therapy to resolve post-traumatic stress disorder on teachers and students of tsunami victims in Banten province. T-test was used with the aim of assisting the decision making in hypothesis testing. The following Table $\mathbf{2}$ describes data on empirical tests of group play therapy techniques to resolve post-traumatic stress disorder.

Table 1. Subjects and objects of study group play therapy for ptsd treatment.

\begin{tabular}{|c|c|c|c|}
\hline Province & M & F & N \\
\hline Lombok, West Nusa Tenggara & 47 & 25 & 72 \\
\hline Palu, Central Sulawesi & 33 & 28 & 61 \\
\hline Anyer, Banten & 26 & 39 & 65 \\
\hline Total & 106 & 92 & 198 \\
\hline
\end{tabular}

M: Male F: Female

Table 2. Test results of the effectiveness of traumatic counseling through group play therapy techniques for handling post traumatic stress disorder.

\begin{tabular}{|c|c|c|c|c|c|}
\hline \multirow{3}{*}{ Dimensions } & \multicolumn{5}{|c|}{$\begin{array}{l}\text { Lombok West Nusa } \\
\text { Tenggara Province }\end{array}$} \\
\hline & \multicolumn{3}{|c|}{ Mean Rank } & \multicolumn{2}{|c|}{$\mathbf{p}$} \\
\hline & $\mathbf{E}$ & $\mathrm{C}$ & $\mathbf{G}$ & 1-tailed & 2-tailed \\
\hline PTSD & -4.74 & -2.19 & -2.55 & 0.05 & 0.021 \\
\hline IM1 & -3.53 & -1.74 & -1.79 & 0.05 & 0.038 \\
\hline IM2 & -3.27 & -1.45 & -1.82 & 0.05 & 0.033 \\
\hline IM3 & -2.40 & -2.83 & 0.43 & 0.05 & 0.193 \\
\hline IM4 & -3.23 & -1.37 & -1.86 & 0.05 & 0.031 \\
\hline IM5 & -3.47 & -1.32 & -2.15 & 0.05 & 0.024 \\
\hline IM6 & -4.61 & -2.57 & -2.04 & 0.05 & 0.026 \\
\hline \multirow{3}{*}{ Dimensions } & \multicolumn{5}{|c|}{ Palu, Central Sulawesi Province } \\
\hline & \multicolumn{3}{|c|}{ Mean Rank } & \multicolumn{2}{|c|}{$\mathrm{p}$} \\
\hline & E & $\mathrm{C}$ & $\mathrm{G}$ & 1-tailed & 2-tailed \\
\hline PTSD & -9.11 & -4.37 & -4.74 & 0.05 & 0.018 \\
\hline IM1 & $\begin{array}{l}-6.63 \\
\end{array}$ & -7.12 & 0.49 & 0.05 & 0.126 \\
\hline
\end{tabular}




\begin{tabular}{|c|c|c|c|c|c|}
\hline \multirow{3}{*}{ Dimensions } & \multicolumn{5}{|c|}{$\begin{array}{l}\text { Lombok West Nusa } \\
\text { Tenggara Province }\end{array}$} \\
\hline & \multicolumn{3}{|c|}{ Mean Rank } & \multicolumn{2}{|c|}{$\mathbf{p}$} \\
\hline & $\mathbf{E}$ & $\mathbf{C}$ & $\mathbf{G}$ & 1-tailed & 2-tailed \\
\hline IM2 & -7.49 & -3.18 & -4.31 & 0.05 & 0.021 \\
\hline IM3 & -6.88 & -7.09 & 0.21 & 0.05 & 0.118 \\
\hline IM4 & -8.22 & -5.29 & -2.93 & 0.05 & 0.036 \\
\hline IM5 & -7.83 & -4.38 & -3.45 & 0.05 & 0.024 \\
\hline IM6 & -7.65 & -3.08 & -4.57 & 0.05 & 0.020 \\
\hline \multirow{3}{*}{ Dimensions } & \multicolumn{5}{|c|}{ Anyer, Banten Province } \\
\hline & \multicolumn{3}{|c|}{ Mean Rank } & \multicolumn{2}{|c|}{$\mathrm{p}$} \\
\hline & $\mathrm{E}$ & $\mathrm{C}$ & $\mathrm{G}$ & 1-tailed & 2-tailed \\
\hline PTSD & -5.74 & -2.44 & -3.30 & 0.05 & 0.011 \\
\hline IM1 & -4.07 & -1.74 & -2.33 & 0.05 & 0.019 \\
\hline IM2 & -3.63 & -1.45 & -2.18 & 0.05 & 0.025 \\
\hline IM3 & -4.82 & -2.12 & -2.70 & 0.05 & 0.015 \\
\hline IM4 & -3.23 & -1.39 & -1.84 & 0.05 & 0.035 \\
\hline IM5 & -4.19 & -4.71 & 0.52 & 0.05 & 0.149 \\
\hline IM6 & -4.05 & -2.66 & -1.39 & 0.05 & 0.037 \\
\hline
\end{tabular}

The following are the t-test data obtained from three provinces in Indonesia: In Lombok, West Nusa Tenggara province, the results of the calculation of the value $\mu_{2}=0.021$. As the value of $\mu_{1>} 0.05$, then Ho is not accepted. In Palu, Central Sulawesi Province, the results of the calculation of the value of $\mu_{2}=0.018$. As the value of $\mu_{1}>0.05$, then Ho is not accepted. In Anyer, Banten Province, the results of the calculation of the value of $\mu_{2}=0.011$. As the value of $\mu_{1}>$ 0.05 , then Ho is not accepted. Therefore, traumatic counseling through the group play therapy technique gives the effect of reducing posttraumatic stress disorder in victims of the tsunami disasters in Lombok Province (West Nusa Tenggara Province), Palu (Central Sulawesi Province), and Anyer (Banten Province).

The empirical test results on the PTSD dimensions of IM1, IM2, IM4, IM5, and IM6 of the victims of natural disasters in Lombok showed that Ho was not accepted; however, the Ho of IM3 empirical dimension of PTSD was accepted.

Empirical test results on the PTSD dimension of group play therapy techniques to resolve posttraumatic stress disorder in victims of natural disasters in Palu (Central Sulawesi Province) showed that Ho was not accepted in the dimensions of IM2, IM4, IM5, and IM6, but was accepted in the IM1 and IM3 dimensions.

The results of the empirical test in Anyer (Banten Province) showed that Ho was not accepted in the dimensions of IM1, IM2, IM3, IM4, and IM6, but was accepted in IM5 dimension.

The study found that the highest average difference in Lombok (West Nusa Tenggara Province) was in the IM5 dimension with -2.15 and IM6 with -2.04 , while the highest average difference in Palu (Central Sulawesi Province) was in the IM6 dimension with -4.57 and IM2 dimension with -4.32 . The highest average difference in Anyer (Banten Province) was in the IM3 dimension with -2.70 and IM1 dimension with -2.33 . In general, this means teaching and practising traumatic counselling techniques through group play therapy can help and make real changes to the victims of natural disasters suffering from PTSD.

\section{DISCUSSION}

The findings show that group play therapy has a significant overall effect on effective PTSD management. This is because playing is a natural expression of preadolescents where they can express their feelings and fantasies and channel the problems and conflicts they have. Accordingly, playing can be categorized as cathartic media [29, 30].

Preadolescents also use games as a language in communicating with the therapists. Games foster empathy on both sides and facilitate the process of more functional interpersonal relationships. Furthermore, preadolescents tend to be able to establish effective communication through play. In psychodynamic and client-centred therapy, effective communication is part of the therapeutic process [2, 31].

Play also acts as a vehicle that enhances understanding and facilitates the counselling process. The emotional resolution of conflict and trauma indicates the success of the therapy process. In the process of playing, preadolescents can experience and solve the traumatic problems faced in everyday life. This view is in line with [32,33], Freud, and Klein, who agree that working through and mastery are important to change mechanisms as a result of the therapy process.

In practice, play involves various actions, namely pretence and the use of fantasy and symbolism. In line with this statement, $[9,34]$ it is explained that playing pretend is a symbolic behavior that considers "one thing to be treated pleasantly as if it were another."

The following Table $\mathbf{3}$ presents a group play therapy model for the management of PTSD victims of natural disasters that are adjusted to the results of need assessment ranging from aspects and symptoms of PTSD, the goals of PTSD treatment and group play therapy. 


\subsection{Dynamics of the Effectiveness of Group Play Therapy Models for PTSD Handling}

Group counselling model was used in the counselling process. There are four stages in the process, namely a) initial, b) transition, c) work, and d) determination. The essence and purpose of each stage are explained as follows.

The initial stage is a facilitating phase where preadolescents victims of PTSD: (1) begin to form groups, (2) start contracts and group goals, (3) distribute group tasks, (4) understand the determination of boundaries, and (5) begin building positive relationships among members. At this stage, verbal conversations like this would arise: "hey kamu sini duduknya, kita harus jadi kelompok yang terkuat" (Hi you, sit here. We should become the strongest group). The ice-breaking game strategy was used at this stage. The games used include Nameplate, Chain Balls and Tree of Hope games.

The Transition Phase is marked by the preadolescents: (1) reaching an agreement in force in the group, (2) beginning to form readiness in taking risks, (3) beginning to set the agenda of activities, (4) increasing intimacy among group members, (5) building more intensive emotional relationships, and (6) beginning to be ready to accept assignments within members. The readiness phase for accepting assignments among the members is divided into two, namely, storming and norming. In the storming stage, counseling is more focused on efforts to discuss group problems and facilitate harmonious communication where a verbal conversation like "boleh kita sama-sama pecahkan pekerjaan ini yang baik, iya hayuu semangat kawan" could emerge, and sharpen interactions. While at the norming stage, counseling is focused on expressing ideas, distributing tasks and the roles of group members. Warming up and energizing group games strategies were used at this stage. The games include Capture the Flag, Yells and Mars Groups, Arrange Lines, Hula-hoop 1, Hulahoop 2, Trust Circle, Trust Fall, and Hand Squeeze.

Table 3. Group play therapy models for PTSD management.

\begin{tabular}{|c|c|c|}
\hline Aspects and symptoms of PTSD & Purpose of recovery & Group games \\
\hline $\begin{array}{c}\text { Exposure to Stressor } \\
\text { a. Dreaming of feeling constantly overshadowed by tragic events that } \\
\text { occur } \\
\text { b. Feel like experiencing a tragic event that happened } \\
\text { c. Having headaches /nausea/allergies when confronted with symbols } \\
\text { of logical events that occur } \\
\text { d. Having a sleep disorder (lots of sleep or difficulty sleeping) } \\
\text { e. Anxious and panic when events occur unexpectedly. }\end{array}$ & Remove traumatic shadows & $\begin{array}{l}\text { 1) Titi my name is a crocodile } \\
\text { 2) Chain ball } \\
\text { 3) Holahop } \\
\text { 4) Shipwreck } \\
\text { 5) Ecor } \\
\text { 6) Tile is leaking }\end{array}$ \\
\hline $\begin{array}{l}\text { Event Re-Experienced } \\
\text { a. Be vigilant beyond reasonable limits on personal safety } \\
\text { b. Difficulty in concentrating on learning or thinking } \\
\text { c. Feeling uncomfortable anywhere } \\
\text { d. Feel people do not care } \\
\text { e. Excessive suspicion of new people }\end{array}$ & Increases the ability to think more rationally & $\begin{array}{l}\text { 1) Capture the flag } \\
\text { 2) Yells and mars group } \\
\text { 3) Compose line } \\
\text { 4) Trust circle } \\
\text { 5) Trust fall } \\
\text { 6) Hand squeeze } \\
\text { 7) Spider weeb } \\
\text { 8) Chocolate river } \\
\text { 9) Toxic waste } \\
\text { 10) Traffic jump }\end{array}$ \\
\hline $\begin{array}{c}\text { Avoidance } \\
\text { a. Loss of interest in re-doing activities that can be carried out before a } \\
\text { tragic event } \\
\text { b. Waiting for God's will in facing } \\
\text { c. Feeling the existence of life is meaningless since experiencing a } \\
\text { tragic event } \\
\text { d. Feeling helpless } \\
\text { e. Feel very disappointed with the situation }\end{array}$ & Aroused an interest in the reality of life & $\begin{array}{l}\text { 1) Line } \\
\text { 2) Trust circle } \\
\text { 3) Trust fall } \\
\text { 4) Spider web } \\
\text { 5) Chocolate river } \\
\text { 6) Positive Appreciation } \\
\text { 7) Broken square }\end{array}$ \\
\hline $\begin{array}{c}\text { Arousal } \\
\text { a. Easily angry } \\
\text { b. Do not want to budge even in the wrong position } \\
\text { c. Insist on opinion/talk } \\
\text { d. Easy to cry } \\
\text { e. Easily offended }\end{array}$ & Restore confidence & $\begin{array}{l}\text { 1) Line } \\
\text { 2) Trust circle } \\
\text { 3) Trust fall } \\
\text { 4) Spider web } \\
\text { 5) Chocolate river } \\
\text { 6) Ring Rah } \\
\text { 7) Rotate the Bottle } \\
\text { 8) Positive Award } \\
\text { 9) Gatrik }\end{array}$ \\
\hline
\end{tabular}




\begin{tabular}{|c|c|c|}
\hline Aspects and symptoms of PTSD & Purpose of recovery & Group games \\
\hline $\begin{array}{c}\text { Isolate Self } \\
\text { a. Refuse to be visited by strangers } \\
\text { b. Difficult to interact with other people } \\
\text { c. Prefer silence } \\
\text { d. Feeling isolated from others } \\
\text { e. Withdrawal from associating with other people or the environment }\end{array}$ & $\begin{array}{l}\text { Restoring attachment and connection with } \\
\text { others who can provide support and } \\
\text { attention, care, and emotional }\end{array}$ & $\begin{array}{l}\text { 1) Line } \\
\text { 2) Trust circle } \\
\text { 3) Trust fall } \\
\text { 4) Spider web } \\
\text { 5) Chocolate river } \\
\text { 6) Ring rah } \\
\text { 7) Rotate the bottle } \\
\text { 8) Positive Award } \\
\text { 9) Broken square } \\
\text { 10) Toxic waste } \\
\text { 8) Nail bottle } \\
\text { 9) Ninja Turtles } \\
\text { 10) Oray-orayan } \\
\text { 11) Ucing sumput }\end{array}$ \\
\hline $\begin{array}{l}\text { Life Disrupted } \\
\text { a. Feeling a bleak future } \\
\text { b. Feeling that no effort can be made to recover from the tragic events } \\
\text { that have occurred } \\
\text { c. Feel no longer have pride in yourself } \\
\text { d. There is no hope that things will get better } \\
\text { e. Feeling hopeless }\end{array}$ & Returns the meaning and purpose of life & $\begin{array}{l}\text { 1) Line } \\
\text { 2) Trust circle } \\
\text { 3) Trust fall } \\
\text { 4) Spider web } \\
\text { 5) Chocolate river } \\
\text { 6) Ring rah } \\
\text { 7) Rotate the bottle } \\
\text { 8) Positive award } \\
\text { 9) Broken square } \\
\text { 10) Toxic waste } \\
\text { 11) Nail bottle } \\
\text { 12) Ninja turtles } \\
\text { 13) Oray-orayan } \\
\text { 14) Ecor } \\
\text { 15) Leaking barrel } \\
\text { 16) Ucing sumput } \\
\text { 17) Bandung pole } \\
\text { 18) Gobag }\end{array}$ \\
\hline
\end{tabular}

The Performance Stage is marked by the preadolescents (1) beginning to form productive work teams, (2) going through the process of "release of tension" and insight, (3) creating opportunities for self-development, and (4) having "honeymoon" among members. At this stage, the counseling process is focused on forming effective groups (teamwork), building group cohesiveness, and releasing tension. The strategy used in this stage is the use of games that are solving problems (problem-solving initiatives), whether committed inside or outside the room. The games used at this stage include traditional games such in-bond as Congkak and Pacublek-cublek Uang, traditional out-bond games such as Bebentengan, Ecor, Oray-orayan, Susumputan, Kalangkang Ucing, Uber Peungpeun, Uiling Kuriling, and Galah Bandung, Nontraditional games -in-bond like Looking for Seats, I Want to Enter, All Doing What Goddess Does, Safeguarding Treasures, Shipwrecks, and a New Identity, non-traditional games -out-bond like Spider Web, Traffic Jam, Blind Trust Walk, Nitro Crossing and Bottle Nails.

Concluding stage is marked by: (1) reflection of experiences during the previous stages, which verbally is manifested in statements such as "yah seneng bisa bermain sama teman lain, bisa ketawa-ketawa", "saya siap kalau nanti ada bencana datang ke sini" (It's great to be playing and laughing with friends. I am prepared if another disaster should strike again here); (2) processing memory; (3) evaluating what has been learned; (4) expressing difficult feelings with verbal manifestations such as "senang bisa mengikuti kegiatan dan merasa plong perasaan takut" (I am happy to have been involved in this activity and feel relieved from fear) dan (5) decision making. The purpose of this termination stage is to: (1) review the group's experience, (2) assess members' growth and change, (3) solve problems (problem-solving), (4) add feedback (feedback), (5) make a farewell address, and (6) plan resolution/problem-solving. The strategy used here is to choose a game that concludes or gives feedback (framing). Games used at this stage include Spinning the Bottle, Ring rah, Positive Award, and Creative Feedback.

Group play therapy is used as an effort to stimulate emotional recovery, through play and verbalization so that preadolescents can use symbolic ways to express their desires. Symbolic emotional recovery always has more therapeutic effect than direct demonstration [35 - 37].

The following are the findings on the use of group play therapy to deal with PTSD:

(1) Groups tend to promote spontaneity in preadolescents, which will increase the degree of participation in play. The counsellor's efforts to communicate the leeway are driven by group dynamics, to free preadolescents from the risk of involvement in various game behaviors.

(2) The effective lives of preadolescents are included in two levels, namely the intrapsychic issue of individual group members and the interpersonal issue between the counsellor and group members.

(3) Preadolescents learn about the feelings felt by others and the relief that takes place in each unit group. The form of application is that preadolescents observe the emotional expressions and behavior of other group members, learn how to 
cope with behavior, learn problem-solving skills, and directed to find alternative ways to express themselves. When preadolescents see other group members involved in activities that initially make them cautious or anxious, then the next time they will have the courage to explore.

(4) Preadolescents have the opportunity for selfdevelopment and self-exploration. This process is facilitated by the responses and reactions of group members to emotional expressions and behavioral expressions. Preadolescents have the opportunity to reflect on and achieve the ability to understand themselves when they evaluate and repeat their self-evaluation through input from fellow friends.

(5) Groups provide a significant opportunity to put preadolescents in the real world. Boundary determination and reality testing occur not only between therapists and individual group members but also among themselves because the group functions as a real microcosm of the community. Therefore, the experience of group therapy is significantly associated with reality.

(6) Game therapy groups function as a microcosm of society. In connection with this opinion, therapists have the opportunity to gain a substantial perspective through the appearance of preadolescents in their daily lives. This real-life perspective can be seen in the microcosm that is proven in the playroom.

(7) Group play frameworks can reduce needs and the tendency to repeat or withdraw from fantasy games even if these behaviors may be needed by some preadolescents in the processing of the issues they face. Besides, the group play framework can bring preadolescents who are stopped in repetition or fantasy into the here-and-present situation.

(8) Preadolescents have the opportunity to practice the skills used in everyday life. Group play therapy provides opportunities for preadolescents to develop abilities in the form of interpersonal skills, mastering new behaviors, offering and receiving assistance, and the ability to experiment using alternative expressions of emotion and behavior.

(9) The presence of more than one preadolescent within the framework of game therapy can be a contributing factor in the development of a therapeutic relationship for some preadolescents. When preadolescents who like to pull away observe a therapist building trust with other preadolescents, they are often encouraged to participate in it. This situation helps reduce the anxiety of preadolescents who feel unsure about the state of the playroom and therapists working in it.

This research has been limited in its samples to junior high school students with PTSD. Subsequent researchers may want to explore how group play therapy can be applied to children or adults.

\subsection{Process Model Group Play Therapy for PTSD Treatment}

Implementation of group play therapy using the Socratic method. This method uses a four-step activities: a) experience, b) identify, c) analyze, and d) generalize [12, 38, 39].

The experience phase, also called the action phase, is the phase when the counsellor carries out counselling activities (do), which are directed at facilitating the individual to express feelings that are a psychological burden following the predetermined scenarios.

The identification phase is the phase when the counsellor carries out the process of identifying and reflecting on experiences during the training process. In this phase, the client or group members are asked to reflect or look into themselves, what is the relationship between the process of the game and his condition. At this stage, the client is invited to express thoughts, feelings associated with the process of experimentation. The thoughts and feelings expressed by the client represent psychological conditions and the problems they face.

The analysis phase is the phase when the client is invited to reflect and think about the relationship between the counselling process and the psychological condition that is being faced. Therefore, this phase can be used to make plans for the improvement of self-weaknesses.

The generalization phase is the phase when the client is invited to make planned improvements to the weaknesses faced by the client. Improvement plans can be realized in the next counselling process.

\section{CONCLUSION}

The group play therapy technique is effective in reducing post-traumatic stress disorder of tsunami victims in Lombok (West Nusa Tenggara Province), Palu (Central Sulawesi Province) and Anyer (Banten Province). While empirical test results on the PTSD dimension show that Ho is not accepted in the dimensions of IM1, IM2, IM4, IM5, and IM6, the results of empirical tests on the PTSD dimension show that Ho is accepted in the IM3 dimension.

Group play therapy to resolve PTSD is an effort to express feelings and fantasies associated with problems and conflicts. In addition, preadolescents use play language as a tool to communicate with counsellors. Active labelling by therapists, empathy, and interpretation of games can help preadolescents to feel. Games provide opportunities for preadolescents to practice a variety of ideas, interpersonal behavior, and verbal expression.

\section{LIST OF ABBREVIATIONS}

$$
\begin{array}{ll}
\text { E } & =\text { Experiment } \\
\text { C } & =\text { Control } \\
\text { PTSD } & =\text { General Results Post-traumatic stress disorder } \\
\text { IM1 } & =\text { Exposure to Stressor } \\
\text { IM2 } & =\text { Event Re-Experienced } \\
\text { IM3 } & =\text { Avoidance } \\
\text { IM4 } & \text { Arousal } \\
\text { IM5 } & \text { Isolate Self } \\
\text { IM6 } & \text { Life Disrupted }
\end{array}
$$




\section{ETHICS APPROVAL AND CONSENT TO PARTICIPATE}

Not applicable.

\section{HUMAN AND ANIMAL RIGHTS}

Not applicable.

\section{CONSENT FOR PUBLICATION}

Informed consent was taken from all the participants when they were enrolled.

\section{AVAILABILITY OF DATA AND MATERIAL}

The data supporting the findings of the article are available in the Unit of Guidance and Counseling Studies, Universitas Pendidikan Indonesia. The corresponding author [D.S] of the present work is available for any information about data.

\section{FUNDING}

None.

\section{CONFLICT OF INTEREST}

The authors declare no conflict of interest, financial or otherwise.

\section{ACKNOWLEDGEMENTS}

Thank you to Universitas Pendidikan Indonesia for providing research assistance funds on traumatic counselling for victims of natural disasters in Lombok, Palu, and Banten; thanks to victims of natural disasters who took part in traumatic counselling activities.

\section{REFERENCES}

[1] Lommen MJJ, Engelhard IM, Sijbrandij M, van den Hout MA, Hermans D. Pre-trauma individual differences in extinction learning predict posttraumatic stress. Behav Res Ther 2013; 51(2): 63-7. [http://dx.doi.org/10.1016/j.brat.2012.11.004] [PMID: 23261706]

[2] Almli LM, Fani N, Smith AK, Ressler KJ. Genetic approaches to understanding post-traumatic stress disorder. Int $\mathrm{J}$ Neuropsychopharmacol 2014; 17(2): 355-70. [http://dx.doi.org/10.1017/S1461145713001090] [PMID: 24103155]

[3] Préville M, Lamoureux-Lamarche C, Vasiliadis H-M, et al. The 6month prevalence of posttraumatic stress syndrome (PTSS) among older adults: validity and reliability of the PTSS scale. Can J Psychiatry 2014; 59(10): 548-55.

[http://dx.doi.org/10.1177/070674371405901008] [PMID: 25565688]

[4] Kaduson HG. Release play therapy for children with posttraumatic stress disorder. 2nd ed. Short-term Play Ther. Child 2006; pp. 3-21.

[5] Tay AK, Rees S, Chen J, Kareth M, Silove D. The structure of posttraumatic stress disorder and complex post-traumatic stress disorder amongst West Papuan refugees. BMC Psychiatry 2015; 15(1): 111. [http://dx.doi.org/10.1186/s12888-015-0480-3] [PMID: 25947101]

[6] Lombardo TW, Gray MJ. Beyond exposure for posttraumatic stress disorder (PTSD) symptoms: broad-spectrum PTSD treatment strategies. Behav Modif 2005; 29(1): 3-9. [http://dx.doi.org/10.1177/0145445504270853] [PMID: 15557476]

[7] McCarthy E, Cook JM. Using Prolonged Exposure With an Older Male U.S. Veteran With Childhood Sexual Abuse-Related PTSD. Clin Case Stud 2018.153465011881914

[8] Galek K, Flannelly KJ, Greene PB, Kudler T. Burnout, secondary traumatic stress, and social support. Pastoral Psychol 2011; 60(5): 633-49.

[http://dx.doi.org/10.1007/s11089-011-0346-7]

[9] Trickey D, Siddaway AP, Meiser-Stedman R, Serpell L, Field AP. A meta-analysis of risk factors for post-traumatic stress disorder in children and adolescents. Clin Psychol Rev 2012; 32(2): 122-38. [http://dx.doi.org/10.1016/j.cpr.2011.12.001] [PMID: 22245560]

[10] Bardeen J. J. R., \& Read, J. P. Attentional control, trauma, and affect regulation: A preliminary investigation. Traumatology 2010; 16(3): $11-8$.

[http://dx.doi.org/10.1177/1534765610362801]

[11] Goodman RD, Miller MD, West-Olatunji CA. Traumatic stress, socioeconomic status, and academic achievement among primary school students. Psychol Trauma 2012; 4(3): 252-9.

[http://dx.doi.org/10.1037/a0024912]

[12] Rusmana N. 2009.ppb.upi.edu

[13] Smith P, Yule W, Perrin S, Tranah T, Dalgleish T, Clark DM. Cognitive-behavioral therapy for PTSD in children and adolescents: a preliminary randomized controlled trial. J Am Acad Child Adolesc Psychiatry 2007; 46(8): 1051-61.

[http://dx.doi.org/10.1097/CHI.0b013e318067e288] [PMID: 17667483]

[14] Makinson RA, Young JS. Cognitive Behavioral Therapy and the Treatment of Posttraumatic Stress Disorder: Where Counseling and Neuroscience Meet. J Couns Dev 2012; 90(2): 131-40. [http://dx.doi.org/10.1111/j.1556-6676.2012.00017.x]

[15] Kar N. Cognitive behavioral therapy for the treatment of posttraumatic stress disorder: a review. Neuropsychiatr Dis Treat 2011; 7 167-81.

[http://dx.doi.org/10.2147/NDT.S10389] [PMID: 21552319]

[16] Little SG, Akin-Little A, Somerville MP. Response to trauma in children: An examination of effective intervention and post-traumatic growth. Sch Psychol Int 2011; 32(5): 448-63.

[http://dx.doi.org/10.1177/0143034311402916]

[17] Neuner F, Schauer M, Klaschik C, Karunakara U, Elbert T. A comparison of narrative exposure therapy, supportive counseling, and psychoeducation for treating posttraumatic stress disorder in an african refugee settlement. J Consult Clin Psychol 2004; 72(4): 579-87. [http://dx.doi.org/10.1037/0022-006X.72.4.579] [PMID: 15301642]

[18] Rhoden M-A, Macgowan MJ, Huang H. A systematic review of psychological trauma interventions for juvenile offenders. Res Soc Work Pract 2019.104973151880657

[http://dx.doi.org/10.1177/1049731518806578]

[19] Ehlers A, Clark DM. A cognitive model of posttraumatic stress disorder. Behav Res Ther 2000; 38(4): 319-45.

[http://dx.doi.org/10.1016/S0005-7967(99)00123-0] [PMID: 10761279]

[20] Ehlers A, Clark DM, Hackmann A, McManus F, Fennell M. Cognitive therapy for post-traumatic stress disorder: development and evaluation. Behav Res Ther 2005; 43(4): 413-31.

[http://dx.doi.org/10.1016/j.brat.2004.03.006] [PMID: 15701354]

[21] Shallcross SL, Frazier PA, Anders SL. Social resources mediate the relations between attachment dimensions and distress following potentially traumatic events. J Couns Psychol 2014; 61(3): 352-62. [http://dx.doi.org/10.1037/a0036583] [PMID: 25019539]

[22] Ojiambo D, Bratton SC. International effects of group activity ojiambo, d., \& bratton, s. c. effects of group activity play therapy on problem behaviors of preadolescent ugandan orphans. J Couns Dev 2014; 92(3): 355-65.

[http://dx.doi.org/10.1002/j.1556-6676.2014.00163.x]

[23] Blanco PJ, Ray DC. Play therapy in elementary schools: a best practice for improving academic achievement. J Couns Dev 2011; 89(2): 235-43.

[http://dx.doi.org/10.1002/j.1556-6678.2011.tb00083.x]

[24] Baggerly J, Parker M. Child-centered group play therapy with african american boys at the elementary school level. J Couns Dev 2005; 83(4): 387-96.

[http://dx.doi.org/10.1002/j.1556-6678.2005.tb00360.x]

[25] Creswell W. John, Research Design: Qualitative, Quantitative, and Mixed Methods Approaches. The United Kingdom: Third 2009.

[26] Borg WR, Gall M. Educational Research: An Introduction. London: Routledge 1989.

[27] Green J, Camilli G, Elmore P. Handbook of complementary methods in education research. Mahwah: Lawrence Erlbaum 2006.

[28] Heppner PP, Wampold B, Kivlighan DM. Research Design in Counseling. California: Thomson Brooks/Cole 2008.

[29] Edgar-Bailey M, Kress V. Resolving child and adolescent traumatic grief: creative techniques and interventions. J Creativity Ment Health 2010; 5(2): 158-76.

[http://dx.doi.org/10.1080/15401383.2010.485090]

[30] Brunner M, Palmer S, Togher L, Hemsley B. I kind of figured it out: the views and experiences of people with traumatic brain injury (TBI) 
in using social media-self-determination for participation and inclusion online. Int J Lang Commun Disord 2018.

[PMID: 29873159]

[31] Katsonga-Phiri T, Grant KE, Brown M. Trauma intervention in subsaharan african children: A systematic literature review. Trauma Violence Abuse 2017.152483801771774

[PMID: 29333952]

[32] Ehring T, Quack D. Emotion regulation difficulties in trauma survivors: the role of trauma type and PTSD symptom severity. Behav Ther 2010; 41(4): 587-98

[http://dx doi.org/10.1016/j.beth 2010.04 004] [PMID: 21035621]

[33] Meany-Walen KK, Bratton SC, Kottman T. Effects of adlerian play therapy on reducing students' disruptive behaviors. J Couns Dev 2014; 92(1): 47-56.

[http://dx.doi.org/10.1002/j.1556-6676.2014.00129.x]

[34] Garza Y, Bratton SC. School-based child-centered play therapy with hispanic children: Outcomes and cultural consideration. Int J Play Ther 2005; 14(1): 51-80.

[http://dx.doi.org/10.1037/h0088896]

[35] Nemeroff CB, Bremner JD, Foa EB, Mayberg HS, North CS, Stein
MB. Posttraumatic stress disorder: A state-of-the-science review. J Psychiatr Res 2006; 40(1): 1-21.

[http://dx.doi.org/10.1016/j.jpsychires.2005.07.005]

[PMID: 16242154]

36] Bisson JI, Roberts NP, Andrew M, Cooper R, Lewis C. Psychological therapies for chronic post-traumatic stress disorder (PTSD) in adults. Cochrane Database Syst Rev 2013; (12): CD003388

[http://dx.doi.org/10.1002/14651858.CD003388.pub4]

[PMID: 24338345]

[37] Kennedy SC, Gordon K. Effects of integrated play therapy on relationship satisfaction and intimacy within couples counseling. Fam J (Alex Va) 2017; 25(4): 313-21.

[http://dx.doi.org/10.1177/1066480717732169]

[38] Roth RL. The socratic method reloaded: a rereading to improve a technologically sound education. International Journal of Learning, Teaching, and Educational Research 2016; 15(6): 1-32.

39] Burns LR, Stephenson PL, Bellamy K. The socratic method: empirical assessment of a psychology capstone course. Psychol Learn Teach 2016; 15(3): 370-83.

[http://dx.doi.org/10.1177/1475725716671824]

(C) 2020 Rusmana et al.

This is an open access article distributed under the terms of the Creative Commons Attribution 4.0 International Public License (CC-BY 4.0), a copy of which is available at: https://creativecommons.org/licenses/by/4.0/legalcode. This license permits unrestricted use, distribution, and reproduction in any medium, provided the original author and source are credited. 